\title{
The Effect of a Social-Emotional School-Based Intervention upon Social and Personal Skills in Children and Adolescents
}

\author{
Tania Gaspar ${ }^{1,2,3}$, Ana Cerqueira ${ }^{2,3}$, Cátia Branquinho ${ }^{1,2}$ \& Margarida G. Matos ${ }^{1,2}$ \\ ${ }^{1}$ ISAMB, University of Lisbon, Portugal \\ ${ }^{2}$ Faculty of Human Movement, University of Lisbon, Portugal \\ ${ }^{3}$ CLISSIS, Lusiada University of Lisbon, Portugal \\ Correspondence: Tania Gaspar, Rua da Junqueira n188-198, 1349-001 Lisbon, Portugal.
}

Received: July 12, 2018

Accepted: August 10, 2018 Online Published: September 6, 2018

doi:10.5539/jel.v7n6p57

URL: https://doi.org/10.5539/jel.v7n6p57

\begin{abstract}
In the middle of the $20^{\text {th }}$ century, there was a shift from a skills deficit approach to a positive approach, focused on promoting assets and individual strengths. The role of social-emotional competences became salient.

School is a privileged arena for universal and selective prevention interventions that can help pupils in raising their competence to cope with life challenges in a relaxed, non-violent and effective way. Personal and social-emotional skills play a key role in children and adolescents' development, as well as their behavior towards risk factors and there is a need to evidence-based interventions.

The scale "For me it's Easy" is an evaluation tool for personal and socio-emotional skills and was used to assess the effect of a Social and Emotional Skills Promotion Program. Personal and social skills play a key role in children and adolescents' development, as well as their behavior towards risk factors.

The study includes an intervention group with 960 Portuguese children and adolescents with a mean age of 12.5 years $(\mathrm{SD}=1.61)$ and included were $56.8 \%$ boys of different educational levels. The waiting-list group included 171 children and adolescents; $46.2 \%$ were boys. The mean age was 14.7 years and the SD was 3.3.

The results reveal significant differences in the intervention group related to the competences before and after the intervention, namely in the interpersonal relationships and definition of goal related skills, while in the waiting list group there were no significant differences in the moment before and after the intervention, and the scale "For me it's Easy" can be considered an instrument which contributes to the research and evaluation of intervention in children and adolescents, especially in the prevention and promotion of personal and social skills and healthy development.
\end{abstract}

Keywords: skills, children/adolescents, assessment, intervention program, evidence-based intervention

\section{Introduction}

Adolescents' health related behaviors influence not only their life, wellbeing and health status during adolescence, but also their adult health and even the health of their future children. Health and wellbeing in adolescence must be understood in an ecological perspective; adolescences' health and opportunities are influenced by different factors, such as the individual characteristics; interpersonal relationships with family, friends and other people from their community; the resources of the community; and even in a broader way by the political context (Bronfenbrenner, 2005; Blum \& Dick, 2013). Therefore, it is very important to promote healthy adolescents, to protect young people from risk behaviors and/or promote socioemotional skills to face the inevitable risks. WHO (2014) identified several health issues related to adolescence. Amongst them are mental health, violence, substance use and other addictions, sexual behavior, obesity and sedentary life. In order to improve young people's wellbeing, it is important to build roads for the future that are evidence-based, thus supporting educational, health and social services and policies. It is also fundamental to make recommendations that promote high quality strategies, which must be age and social appropriate for adolescents, and finally, understand health issues for adolescents considering the specificities of risk groups, such as adolescents with low socioeconomic status, adolescents with a low level of education, and migrant adolescents.

Effective school health promotion and prevention programs are amongst the most cost effective investments, 
because both promote health and education (Blum \& Dick, 2013; Gaspar, Matos, Ribeiro, Leal, Erhart, \& Ravens-Sieberer, 2012; WHO, 2014). Adolescents are at school for most of their day, therefore school is a privileged setting for implementing universal and selective prevention interventions that can help adolescents increase their competence to cope with life challenges, namely school failure, interpersonal relationships, health behaviors (addictions, eating behavior and sexual behavior) and emotion related management (Fydenberg, 2008; Matos \& Sampaio, 2009; Matos et al., 2012).

Roth and Brooks-Gunn (2000) claimed that pupils with school failure have higher rates of anti-social behavior, and less subjective wellbeing (Gaspar et al., 2012). Roth et al. (2000) proposed the 3 factors (ABC) related to wellbeing and health related behaviors: Appropriate (school ethos); Behaviors (personal), Connection (interaction). Friends are a source of social capital but also a source of relational problems such as conflict, discrimination and rejection (Morgan, 2007; Matos \& Sampaio, 2009; Matos \& Morgan, 2012). Roth and Brooks-Gunn (2000) stressed issues that can interfere with peer relationship: "FRIEND" Friendship, Resisting (peer pressure), Interests (daily interest and motivations), Examples (social models), Numbers (balance between risk and protection) and Deviant (association with a deviant peer group).

School-based programs have been evaluated regarding their efficacy in promoting personal factors, such as communication skills, cognitive problem solving skills, emotion regulation, social relationships and future expectations, and leisure/work schedule management (Matos, 2005; Matos, 2015). A meta-analysis of after-school programs that seek to enhance the personal and social skills of children and adolescents indicated that, compared to the waiting group participants demonstrated a significant increase in their self-perceptions and bonding to school, positive social behaviors, school grades and levels of academic achievement, and a significant reduction in problematic behaviors (Blum \& Dick, 2013; Matos et al., 2012; Matos, Tomé, Gaspar, Cicognani. \& Moreno, 2016; Reddy, 2013). Durlak, Weissberg, and Pachan (2010) recommended four practices associated to previously effective skill training, namely, SAFE: Sequenced, Active, Focused, and Explicit.

The promotion of personal and social-emotional competence aims at helping people to become aware of their strengths and difficulties in dealing with life, and increasing personal, social and interpersonal competencies such as communication, problem solving, emotion regulation maintenance and promotion of social relationships and social capital and future positive expectation (Matos \& Simões, 2016). Those competencies are associated with a decrease of interpersonal violence and other risk behaviors, by means of increasing the interpersonal repertoire of responses used to deal with threats, challenges and interpersonal difficulties, and increasing subjective wellbeing and quality of life (Gaspar, Matos, Pais-Ribeiro, Leal, \& Albergaria, 2014; Matos et al., 2012). Some groups of adolescents, for instance, being a girl (Gaspar et al., 2012), having special needs education (Gaspar, Bilimória, Albergaria, Matos, 2016), school failure (Gaspar, Rebelo, Mendonça, Albergaria, \& Matos, 2014), having low socioeconomic status (Gaspar \& Balancho, 2016; Gaspar, Matos, Luszczynska \& De Wit, 2016; Reddy, 2013) present more health needs, thus they can be considered risk factors related to health and subjective wellbeing. The impact of those risks, or the developmental and psychological consequences, can be reduced if adolescents develop social and personal skills to face the risk and improve positive developmental opportunities (Blum \& Dick, 2013; WHO, 2014). Identification, expression and management/self-regulation of emotion are a major focus for adequate, relaxed and competent coping strategies (Matos, 2005; Matos et al., 2012; Matos, 2015).

School-based approaches seem to be more effective when they include the entire school (Jané-Llopis \& Barry, 2005), use a social skills promotion model, include peer education, promote student participation and initiative, use interactive and participated methodologies, and become a part of the school culture. New programs should be integrated into existing ones, and partnerships and networking with structures within the community encouraged for a crossed enrichment. New structures, building skills and higher levels of participation are also advised. The 'entire school' and 'entire community' approach join a public health perspective and are based on positive psychology that privileges the development of positive traits (positive emotions, resilience and optimism) and highlight the 4D's from the Appreciative Inquiry (Discover, Dream, Design, Deliver): Discover what people value, Dream that changes match what people value, Design ways to change, and Deliver a proper intervention to reach these objectives (Jané-Llopis, Barry; Hosman, \& Patel, 2005). Studies on school interventions that aim to promote social and emotional wellbeing suggest that problem solving is the best short-term strategy for the promotion of pro-social behaviors, although peer mediation provides long-term success (Blank et al., 2010).

The last international Health Behavior School-Aged Children report (Inchely et al., 2016), a collaborative study of World Health Organization, identifies meaningful differences in the prevalence of health and social indicators by gender, age group and levels of family affluence. The findings highlight important health inequalities and contribute to a better understanding of the social determinants of health and well-being among young people. 
Gender and social conditions are important variables to characterize, understand and intervene in adolescents' health protection and promotion (Matos \& Aventura Social, 2012).

On the one hand, related to gender differences, boys in general engage more in externalizing or expressive forms of health behaviors, such as drinking or fighting, while girls tend to deal with health issues in a more emotional or internalizing way, often manifesting as psychosomatic symptoms or mental health problems.

Clear differences between gender and age can be found in children and adolescents' subjective wellbeing. For instance, the girls' perception of their wellbeing is inferior in all dimensions with the exception of "Social Support and Peers", "School Environment" and "Social Acceptance and Bullying". Adolescents (the older group, ages between 12 and 16 years old) presented an inferior perception of wellbeing in all measures except in the "Financial Resources" and "Social Acceptance and Bullying" (Bisegger et al., 2005; Ravens-Sieberer et al., 2001; 2005; The KIDSCREEN Group Europe, 2006).

Gender differences for some health behaviors tend to increase during adolescence, indicating that this is a crucial period for the development of health differentials that may track into adulthood. Targeting adolescents' health from a gender perspective has considerable potential to reduce health differentials based on gender in adulthood. On the other hand, evidence collected over the last few decades shows that low socio economic situations are associated with increased health risks and less access to health and health education. As a result, health inequalities are now highlighted in contemporary international policy development. The WHO Commission on Social Determinants of Health claims that the vast majority of inequalities in health, within and between countries, are avoidable and yet they continue to be experienced by young people across Europe (Inchley et al., 2016).

The purpose of the present work is to evaluate a school based intervention aiming at promoting social-emotional competence, using a tool (For me it's easy) which is specifically designed and validated (Gaspar \& Matos, 2015).

\section{Method}

\subsection{Participants}

The experimental group included 960 children and adolescents, $56.7 \%$ were boys. In terms of age group, $24.5 \%$ were aged 8 to 12 years, $25.1 \%$ from 13 to 15 years and $50.4 \%$ were 16 or more years old. The mean age was 15.3 years and the SD was 3.7.

The waiting group, used in pre and post intervention analyses (Table 5), included 171 children and adolescents, $46.2 \%$ were boys. In terms of age group, $27.2 \%$ were aged 8 to 12 years, $27.8 \%$ from 13 to 15 years and $45.1 \%$ with 16 or more years. The mean age was 14.7 years and the $S D$ was 3.3 .

\subsection{Instrument}

The instrument was built based on the social skills checklist (Goldstein \& McGinnis, 1997) and the emotional self-regulation questionnaire (Moilanen, 2007). According to international guidelines, the translation of some items of the questionnaires included a back translation process. The initial scale had 50 items and was tested with children, adolescents, teachers of 1st, 2nd and 3rd cycles and psychologists. Suggestions and contributions indicated by these, namely, in the exclusion of some items and words changing on others, were included in the final version used here. The final version consists of 43 items that include competencies from the simplest to the most complex, in the various contexts of the children and adolescents, such as "For me it's easy to say thank you"; "It is easy for me to defend my rights"; "It's easy for me to deal with schoolmates." Several items are to be inversed and are marked with * (Table 3). Two complementary instruments were also used to deepen the study of the "For me it's easy" scale. One of the complementary instruments evaluates a personal variable (Subjective well-being) and another evaluates a social variable (Social support). The study of the instrument found significant statistical age differences. For almost all variables, younger students presented a more positive perception related to socioemotional skill's dimensions. In relation to interpersonal skills, significant statistical age and gender differences were found. On one hand, boys presented a more positive perception related to subjective wellbeing, social support and some of the socioemotional skills, such as problem solving and emotional regulation. On the other hand, girls presented a more positive perception related to basic skills and interpersonal relationship (Gaspar, Cerqueira, Branquinho, \& Matos, 2018).

\subsection{Procedure}

This study is a research-action that aims to evaluate the impact of a personal and social skills promotion program in children and adolescents developed by a CED, called ISC (Integrated Social Competencies). The initiative to 
carry out the project started from the schools involved. Thus, after deciding the directions of the schools involved, the objectives of the study were presented to the school community (teachers, students and parents). The data collection was carried out with students from 4 schools in Lisbon. A waiting-list group of participants were used. The parents gave their informed consent. The instrument was self-fulfillment and voluntary participation. The evaluation was carried out before and after the implementation of the ISC competences program to assess the impact of the intervention. The program involves the implementation of 22 group sessions, each school year. The implementation of the program was carried out by teachers and psychologists. The application was made in the classroom context.

The overall objective of the ISC program is to develop personal and social skills related to knowledge of self, communication, interpersonal relationships and decision making. Those skills are developed through relational dynamics, the experience and communication integrators, difficulties and conflicts linked around interpersonal relationships and health behaviors, related to sexuality, substance use, life styles and mental health. The main contents that are approached with participants are: Interpersonal communication; Assertiveness; Conflict management; Problems solving; and Emotional management. The developed activities depended on each group's specific characteristics and needs. Used were manuals and different materials including stories, music, games and group dynamics. Each session presented the same global structure, including an initial review activity (relevant events since the last session) and ice-breaking, an activity related with the content and objective of the session, a cooperation activity and a final activity of reflection regarding the session and the work to develop until the next session.

\subsection{Data Analysis}

For the data analysis, SPSS 20 software was used to perform descriptive statistical analysis, exploratory factorial analysis, correlations and ANOVA (repeated measures) to evaluate changes before and after the program.

\section{Results}

Previous publications using this tool "For me it's easy" revealed good metric properties.

The factorial exploratory analysis was forced to 5 factors and presents a cumulative explained variance of $40.19 \%$. The Eigenvalue for the first factor is 10.45 which explains $24.30 \%$ of the variance, the Eigenvalue for the second factor is 2.08 which explains $4.85 \%$ of the variance, the Eigenvalue for the third factor is 1.67 which explains $3.88 \%$ of the variance, the Eigenvalue for the fourth factor is 1.61 which explains $3.74 \%$ of the variance, the Eigenvalue for the fifth factor is 1.48 which explains $3.43 \%$ of the variance (Table 1 ).

Table 1. Factor analysis and the 5 dimensions of the social and personal competence instrument

\begin{tabular}{|c|c|c|c|c|c|}
\hline \multirow[b]{2}{*}{ Items } & \multicolumn{5}{|c|}{ Dimensions } \\
\hline & $\begin{array}{l}\text { Problem } \\
\text { Solving }\end{array}$ & Basic Skills & $\begin{array}{l}\text { Emotional } \\
\text { Regulation }\end{array}$ & $\begin{array}{l}\text { Interpersonal } \\
\text { Relationships }\end{array}$ & Defining Goals \\
\hline 26-To make choices & 0.65 & & & & \\
\hline 25-To understand my problems & 0.61 & & & & \\
\hline 9-To understand my feelings & 0.58 & & & & \\
\hline 42-To find someone to help me when I need to & 0.57 & & & & \\
\hline $\begin{array}{l}\text { 28-To start doing something that makes me feel } \\
\text { better. when I'm sad }\end{array}$ & 0.57 & & & & \\
\hline $\begin{array}{l}\text { 22-To figure out what happened when I have a } \\
\text { problem }\end{array}$ & 0.55 & & & & \\
\hline 23-To know what I want & 0.55 & & & & \\
\hline $\begin{array}{l}\text { 43-To understand when I am living in a difficult } \\
\text { situation and it is better to ask for help }\end{array}$ & 0.55 & & & & \\
\hline 24-To recognize what I am good at & 0.52 & & & & \\
\hline 21-To know what to do in complicated situations & 0.49 & & & & \\
\hline 30-To start a new conversation even when I'm tired & 0.48 & & & & \\
\hline 7-To ask for help & 0.44 & & & & \\
\hline 10-To show my feelings & 0.43 & & & & \\
\hline $\begin{array}{l}\text { 39-To concentrate on my work. even when my } \\
\text { colleagues are talking }\end{array}$ & 0.41 & & & & \\
\hline 29-To change my behavior to get what I want & 0.39 & & & & \\
\hline 4-To say "thank you" & & 0.66 & & & \\
\hline 8-To apologize & & 0.65 & & & \\
\hline
\end{tabular}




\begin{tabular}{|c|c|c|c|c|c|}
\hline 13-To share things & & 0.53 & & & \\
\hline 12-To ask for permission & & 0.53 & & & \\
\hline 6-To praise & & 0.49 & & & \\
\hline 27-To help someone who needs help & & 0.47 & & & \\
\hline 20-To deal with teachers & & 0.42 & & & \\
\hline 19-To deal with classmates at school & & 0.35 & & & \\
\hline 14- To "control myself" & & & 0.65 & & \\
\hline 35-To speak quietly. without getting upset. when I & & & 0.64 & & \\
\hline have a quarrel with someone & & & & & \\
\hline 17-To calm down when I have a difficult situation & & & 0.64 & & \\
\hline 36-To calm down when I am excited & & & 0.54 & & \\
\hline 38-Not to overreact when I am angry & & & 0.52 & & \\
\hline $\begin{array}{l}\text { 41-Not to do something. when I know I shouldn't do } \\
\text { it }\end{array}$ & & & 0.42 & & \\
\hline 1-To listen to other people & & & 0.37 & & \\
\hline 5-To approach a person I do not know & & & & 0.57 & \\
\hline $\begin{array}{l}\text { 18-To say "no" when someone tries to convince me } \\
\text { of something }\end{array}$ & & & & 0.54 & \\
\hline 15-To defend my rights & & & & 0.53 & \\
\hline 2-To start and hold a conversation & & & & 0.53 & \\
\hline 3-To ask questions & & & & 0.45 & \\
\hline 11-To understand the feelings of others & & & & 0.34 & \\
\hline 37-To know when I am about to cry & & & & 0.30 & \\
\hline 16-To complain & & & & 0.26 & \\
\hline $\begin{array}{l}31 \text {-To get nervous when things do not go the way I } \\
\text { want* }\end{array}$ & & & & & 0.66 \\
\hline $\begin{array}{l}\text { 33-To forget important tasks when I'm doing } \\
\text { something truly fun* }\end{array}$ & & & & & 0.65 \\
\hline $\begin{array}{l}\text { 32-Not to remember my goals when small problems } \\
\text { appear* }\end{array}$ & & & & & 0.64 \\
\hline $\begin{array}{l}\text { 34-To have difficulty in paying attention during a } \\
\text { boring class* }\end{array}$ & & & & & 0.56 \\
\hline $\begin{array}{l}\text { 40- To let myself be carried away by emotions when I } \\
\text { get excited* }\end{array}$ & & & & & 0.52 \\
\hline Eigenvalues & 10.45 & 2.08 & 1.67 & 1.61 & 1.48 \\
\hline Explained variance & 24.30 & 4.85 & 3.88 & 3.74 & 3.43 \\
\hline
\end{tabular}

*Inverted items

The analysis of the "For me it's easy" scale for the psychometric properties showed good internal consistency for the full scale $(\alpha=0.92)$ and for all 5 dimensions with values between $\alpha=0.87$ in "Problem Solving" and $\alpha=0.62$ in the "Goal Setting". (Table 2) and supported a 5 factor factorial structure (Gaspar \& Matos, 2015) (Table 2)

Table 2. Descriptive data, internal consistency of the total scale and the 5 dimensions of the social and personal competence instrument

\begin{tabular}{llllll}
\hline Dimensions & Number items & $N$ & $M$ & $S D$ & $\alpha$ \\
\hline 1 Global skills (Total) & 43 & 916 & 3.55 & 0.53 & 0.91 \\
2 Problems solving & 13 & 948 & 3.53 & 0.67 & 0.86 \\
3 Basic skills & 10 & 947 & 4.01 & 0.64 & 0.79 \\
4 Emotional regulation & 7 & 950 & 3.33 & 0.72 & 0.74 \\
5 Interpersonal relationships & 8 & 945 & 3.42 & 0.61 & 0.67 \\
6 Defining goals & 4 & 954 & 3.12 & 0.75 & 0.61 \\
\hline
\end{tabular}

Most of the participants presented positive values related to their socioemotional skills dimensions. The highest value was related to Basic Skills $(M=4.01)$ and the lowest value was related to Defining Goals $(M=3.12)$ and Emotional Regulation $(M=3.33)$. 
Table 3. Factorial structure and inter-scale correlations - correlations between socioemotional skills dimensions

\begin{tabular}{|c|c|c|c|c|c|c|c|}
\hline & 1 & 2 & 3 & 4 & 5 & 6 & 7 \\
\hline 1 Global skills(Total) & --- & & & & & & \\
\hline 2 Problems solving & $0.91 * * *$ & --- & & & & & \\
\hline 3 Basic skills & $0.80 * * *$ & $0.65 * * *$ & --- & & & & \\
\hline 4 Emotional regulation & $0.76^{* * *}$ & $0.62 * * *$ & $0.55^{* * *}$ & --- & & & \\
\hline 5 Interpersonal relationships & $0.76 * * *$ & $0.57 * * *$ & $0.54 * * *$ & $0.44 * * *$ & --- & & \\
\hline 6 Defining goals & $0.42 * * *$ & $0.24 * * *$ & $0.20 * * *$ & $0.17 * * *$ & $0.38 * * *$ & --- & \\
\hline
\end{tabular}

The correlation between Socioemotional Skills dimensions are statistically significant and, in most cases high, range between 0.91 (correlation between Problem Solving and Global Skills) and 0.17 (correlation between Definition of Goals and Emotional Regulation). Problem Solving was the variable with higher correlation with other Socioemotional Skills (Table 3).

In order to study the impact of the intervention program in children and adolescents' socioemotional skills improvement, a pre and post intervention analyses was developed and it's presented in Table 4.

Table 4. Comparison related to socioemotional skills between pre and post test

\begin{tabular}{|c|c|c|c|c|c|c|c|c|c|c|}
\hline & \multicolumn{4}{|c|}{ Intervention group } & \multirow[b]{3}{*}{$\mathrm{F}$} & \multicolumn{5}{|c|}{ Waiting list group } \\
\hline & \multicolumn{2}{|c|}{ Pre test } & \multicolumn{2}{|c|}{ Post test } & & \multicolumn{2}{|c|}{ Pre test } & \multicolumn{2}{|c|}{ Post test } & \multirow[b]{2}{*}{$\mathrm{F}$} \\
\hline & $\mathrm{M}$ & $\mathrm{SD}$ & $\mathrm{M}$ & $\mathrm{SD}$ & & $\mathrm{M}$ & $\mathrm{SD}$ & $\mathrm{M}$ & $\mathrm{SD}$ & \\
\hline 1 Global skills & 3.56 & 0.52 & 3.59 & 0.53 & n.s. & 3.55 & 0.45 & 3.61 & 0.41 & n.s. \\
\hline 2 Problems solving & 3.59 & 0.64 & 3.57 & 0.70 & n.s. & 3.44 & 0.65 & 3.59 & 0.60 & n.s. \\
\hline 3 Basic skills & 4.01 & 0.64 & 3.97 & 0.63 & n.s. & 4.13 & 0.56 & 4.18 & 0.50 & n.s. \\
\hline 4 Emotional regulation & 3.36 & 0.69 & 3.28 & 0.75 & n.s. & 3.33 & 0.71 & 3.32 & 0.67 & n.s. \\
\hline 5 Interpersonal relationships & 3.39 & 0.60 & 3.44 & 0.61 & $5.954 * *$ & 3.49 & 0.55 & 3.56 & 0.51 & n.s. \\
\hline 6 Defining goals & 3.12 & 0.75 & 3.48 & 0.75 & $10.319 * * *$ & 3.20 & 0.70 & 3.12 & 0.69 & n.s. \\
\hline
\end{tabular}

Through the analysis of Table 4 we verified that the intervention group, which was the target of the intervention, reveals significant differences between the competences before and after the intervention, namely in the Interpersonal Relationships and Definition of Goals related skills. While in the waiting-list group, which was not the target of the intervention, there were no significant differences between evaluations.

Table 5. Socioemotional skills between pre and post evaluation, in the intervention group, by gender

\begin{tabular}{|c|c|c|c|c|c|c|c|c|c|c|}
\hline & \multicolumn{4}{|c|}{ Boys } & \multicolumn{6}{|c|}{ Girls } \\
\hline & \multicolumn{2}{|c|}{ Pre } & \multicolumn{2}{|c|}{ Post } & \multicolumn{3}{|c|}{ Pre } & \multicolumn{2}{|c|}{ Post } & \multirow[b]{2}{*}{$\mathrm{F}$} \\
\hline & $\mathrm{M}$ & $\mathrm{SD}$ & $\mathrm{M}$ & $\mathrm{SD}$ & $\mathrm{F}$ & $\mathrm{M}$ & $\mathrm{SD}$ & $\mathrm{M}$ & $\mathrm{SD}$ & \\
\hline 1 Global skills & 3.54 & 0.53 & 3.61 & 0.57 & n.s. & 3.55 & 0.57 & 3.49 & 0.54 & n.s. \\
\hline 2 Problems solving & 3.59 & 0.64 & 3.63 & 0.66 & n.s. & 3.53 & 0.72 & 3.42 & 0.68 & n.s. \\
\hline 3 Basic skills & 3.93 & 0.64 & 3.91 & 0.64 & n.s. & 4.06 & 0.66 & 3.93 & 0.66 & $5.21 * *$ \\
\hline 4 Emotional regulation & 3.36 & 0.69 & 3.48 & 0.72 & $5.34 * *$ & 3.30 & 0.76 & 3.32 & 0.73 & n.s. \\
\hline 5 Interpersonal relationships & 3.36 & 0.61 & 3.48 & 0.63 & $7.42 * *$ & 3.45 & 0.63 & 3.43 & 0.60 & n.s. \\
\hline 6 Defining goals & 3.14 & 0.75 & 3.32 & 0.79 & $9.85 * * *$ & 3.19 & 0.79 & 3.22 & 0.74 & n.s. \\
\hline
\end{tabular}

The study of gender in the pre- and post-intervention period allows us to point out that girls, at the moment before the intervention, present higher values in the Basic Skills.

At the level of Emotional Regulation skills, Interpersonal Relationships and Goals Definition skills, boys from the intervention group presented higher results in the post intervention moment than in the pre intervention moment (Table 5).

\section{Discussion}

School is a privileged arena for universal and selective prevention interventions that can help pupils in raising their competence to cope with life challenges in a relaxed, non-violent and effective way. The personal and social-emotional skills play a key role in children and adolescents' development, as well as their behavior towards risk factors. 
The scale "For me it's Easy" is an evaluation tool of personal and socio-emotional skills and was used to assess the effect of a Social and Emotional Skills Promotion Program. The purpose of the present work is to evaluate a school based intervention aiming at promoting social-emotional competence, using a tool (For me it's easy) which is specifically designed and validated (Gaspar \& Matos, 2015).

The study has included an intervention group with 960 Portuguese children and adolescents, and a waiting group including 171 children and adolescents.

The results reveal significant differences in the intervention group related to the competences before and after the intervention, namely in the interpersonal relationships and definition of goals related skills, while in the waiting group there were no significant differences in the moment before and after of the intervention. That result is coherent with a developmental perspective, that first adolescents develop and consolidate more basic skills and then develop more complex skills, such us defining goals (APA, 2002).

Most of the participants presented positive values related to their socioemotional skill dimensions. The highest value was related to basic skills $(M=4.01)$ and the lowest value was related to defining goals $(M=3.12)$. This was one of the dimensions where significant improvement was achieved between the pre and the post evaluation.

This results are aligned with the literature where it is found that personal and social-emotional competence promotion interventions help people to be aware of their strengths and difficulties dealing with life, and increasing personal, social and interpersonal competences, such as communicating, problem solving, emotion regulation and social relationship, those competences being associated with a decrease of interpersonal violence, by means of increasing interpersonal repertoire of responses used to deal with threats, with challenges and with interpersonal difficulties (Matos, 2005; Matos et al., 2012; Matos, 2015).

Boys tend to improve their level of skills related to Interpersonal Relationships, Goals Definitions and Emotional Regulation. According to the teachers' perception, the skills promotion program has shown to have a greater impact in the development of skills for boys than for girls. On one hand, several studies (Cecconello \& Koller, 2003; Coelho, Marchante \& Sousa, 2015; Del Prette, Teodoro \& Del Prette, 2014; Else-Quest, Hyde, Goldsmith \& Van Hulle, 2006; Hample \& Petermann, 2005; 2006; Leppänen \& Hietanen, 2001; Macdermott, Gullone, Allen, Ring \& Tonge, 2009) revealed that girls present a higher level of social skills. Girls present a higher level of social awareness and social sensibility (Coelho et al., 2015; Macdermott et al., 2009), social empathy (Del Prette et al., 2014), seek more social support (Hampel \& Petermann, 2006), are better at inhibiting inappropriate behavioral responses (Else-Quest et al., 2006), have greater skills in the domain of social cooperation (Faria, 2001) and better skills at the interpersonal level (Leppänen \& Hietanen, 2001) than boys.

On the other hand, girls present more inadequate emotional responses, such as difficulty in dealing with negative emotions, limited access to emotional self-regulation strategies (Neumann, Van Lier, Gratz \& Koot, 2009) and maladaptive coping strategies and a high level of emotional stress (Hampel \& Petermann, 2005; 2006).

Boys present higher levels of self-esteem, self-concept of problem solving (Faria \& Azevedo, 2004), leadership ability (Coelho et al., 2015), social assertiveness (Faria, 2001) and greater emotional stability (Faria \& Azevedo, 2004), when compared to girls.

Differences by age were found; the younger adolescents ( 8 to 12 years old) presented higher levels of social and personal skills when compared with older adolescents (16 or more years old). Younger adolescents present more and adaptive coping strategies and less problems with aggressive and externalized behaviors (Hampel \& Petermann, 2005; 2006).

For interventions to be effective, parents and health and education professionals must have adequate skills and training to meet the specific needs of these target populations. Programs should promote well-being, social and problem solving skills, school attendance and success, and not merely prevent risk behaviors. Older children, girls, poor pupils, migrants and pupils with a chronic disease can easily become disengaged from school and drop out because curriculum, teachers, and school systems as a whole are unable to bridge cultural gaps due to a limited understanding of what school "for all" entails. Furthermore, since risk behaviors are embedded in the psychosocial context, preventive intervention should be implemented at school, family, and community levels. Politicians, educators, health professionals, and other professional groups are encouraged to face the challenge of implementing effective interventions based on an understanding of gender and developmental diversity.

\section{Acknowledgments}

Authors acknowledge Casa Pia de Lisboa. 


\section{References}

Bisegger, C., Cloetta, B., von Rueden, U., Abel, T., Ravens-Sieberer, U., \& the European KIDSCREEN group. (2005). Health-related quality of life: gender differences in childhood and adolescence. Soz.-Präventivmed, 50, 281-291. https://doi.org/10.1007/s00038-005-4094-2

Blum, R., \& Dick, B. (2013). Strengthening Global Programs and Policies for Youth Based on the Emerging Science. Journal of Adolescent Health, 52, S1-S3. https://doi.org/10.1016/j.jadohealth.2012.11.004

Bronfenbrenner, U. (2005). Making human beings human: Bioecological perspectives on human development. Thousand Oaks, CA: Sage.

Currie, C., Hurrelmann, K., Settertobulte, W., Smith, R., \& Todd, J. (2000). Health and health behaviour among young people. HEPCA series: World Health Organisation.

Direção-Geral de Educação. (2014). Programa de apoio à promoção e educação para a saúde. Direção-Geral de Educação, Governo de Portugal, Ministério da Educação e Ciência.

Durlak, J. A., Weissberg, R. P., \& Pachan, M. (2010). A Meta-Analysis of After-School Programs That Seek to Promote Personal and Social Skills in Children and Adolescents. American Journal of Community Psychology, 45(3), 294-309. https://doi.org/10.1007/s10464-010-9300-6

Frydenberg, E. (2008). Adolescent Coping. New York: Psychology Press.

Gaspar, T., \& Balancho, L. (2016). Factores pessoais e sociais que influenciam o bem-estar subjectivo: diferenças ligadas estatuto socioeconómico. Ciência e Saúde Coletiva, 22(4), 1373-1380. https://doi.org/10.1590/1413-81232017224.07652015

Gaspar, T., \& Matos, M. (2015). Para mim é fácil - Escala de avaliação de competências pessoais e sociais. Psicologia, Saúde e Doenças, 16(2), 199-211.

Gaspar, T., Bilimória, H., Albergaria, F., \& Matos, M. (2015). Children and adolescents with Special Education Needs and subjective wellbeing. International Journal of Disability, Development and Education.

Gaspar, T., Bilimória, H., Albergaria, F., \& Matos, M. G. (2016). Children with Special Education Needs and Subjective Well-being: Social and Personal Influence. International Journal of Disability, Development and Education, 63(5), 500-513. https://doi.org/10.1080/1034912X.2016.1144873

Gaspar, T., Cerqueira, A., Branquinho, C., \& Matos, M. (2018). Dimensions of Social and Personal Skills in children and adolescents: age and gender differences. International Journal of Development Research.

Gaspar, T., Matos, M. G., Foguet, J., Ribeiro, J. L., \& Leal, I. (2010). Parent-child perceptions of quality of life: Implications for health intervention. Journal of Family Studies, 16(2), 143-154. https://doi.org/10.5172/jfs.16.2.143

Gaspar, T., Matos, M. G., Pais Ribeiro, J., Leal, I., \& Albergaria, F. (2014). Psychosocial Factors Related to Bullying and Victimization in Children and Adolescents. Health Behavior \& Policy Review, 1(6), 452-459. https://doi.org/10.14485/HBPR.1.6.3

Gaspar, T., Matos, M. G., Ribeiro, J.L., Leal, I., Erhart, M., \& Ravens-Sieberer, U. (2012). Health-related quality of life in children and adolescents: subjective wellbeing. Spanish Journal of Psychology, 15(1), 177-186. https://doi.org/10.5209/rev_SJOP.2012.v15.n1.37306

Gaspar, T., Matos, M., Luszczynska, A., \& De Wit, J. (2016). Socio-economic and self-regulatory influences on Eating behavior in children and adolescents from four European countries. North American Journal of Psychology, 18(1), 177-192.

Gaspar, T., Rebelo, A., Mendonça, I., Albergaria, F., \& Matos, M. (2014). Subjective wellbeing and School Failure in children and adolescents: influence of psychosocial factors. International Journal of Development Research, 4(11), 2194-2199.

Gaspar, T., Santos, T., \& de Matos, M. G. (2016). Relationship between Subjective Wellbeing and Weight Perception in Children and Adolescents: Gender and Age Differences. Child Indicators Research.

Goldstein, A. P., \& McGinnis, E. (1997). Skill streaming the Adolescents: New strategies and perspectives for teaching prosocial skills (Rev. ed.). Champaign, IL: Research Press.

GTES. (2007). Relatório Final do Grupo de Trabalho para a Educação Sexual Ministério da Educação (GTES Ministerial Commission for the sexual health education - final report). Retrieved from http://www.dgidc.minedu. pt/EducacaoSexual 
Inchley, J. et al. (Eds.). (2016). Growing up unequal: gender and socioeconomic differences in young people's health and well-being. Health Behaviour in School-aged Children (HBSC) study: international report from the 2013/2014 survey. Copenhagen, WHO Regional Office for Europe, 2016 (Health Policy for Children and Adolescents, No. 7).

Jané-Llopis, E., \& Barry, M. (2005). What makes mental health promotion effective? IUHPE, Promotion and Education supplement, 2, 47-54.

Jané-Llopis, E., Barry, M., Hosman, C., \& Patel, V. (2005). Mental health promotion works: a review? IUHPE, Promotion and Education supplement, 2, 9-25. https://doi.org/10.1177/10253823050120020103x

Matos, M. G. (2005). Comunicação, gestão de conflitos e saúde na escola, (Communication, conflict management and health in school). Lisboa: CDI/ FMH.

Matos, M. G. (2015). Adolescents in safe navigation through unknown waters. Lisbon: Coisas de Ler.

Matos, M. G., \& Morgan, A., (2012). Roads to whatever? Or roads to a self-fulfilled future?: health assets and well-being in children and adolescents. In Fundação Calouste Gulbenkian, Roads to Whatever (pp. 61-85). Lisboa: Fundação Calouste Gulbenkian.

Matos, M. G., \& Sampaio, D. (2009). Jovens com saúde: Diálogos com uma geração; (Youths with health: dialogue with a generation). Lisboa: Texto Editores.

Matos, M. G., \& Simões, C. (2016). From Positive Youth Development to Youth's Engagement: the Dream Teens. The International Journal of Emotional Education, 8(1), 4-18.

Matos, M. G., Gaspar, T., \& Simões, C. (2012). Health-related quality of life in Portuguese children and adolescents. Qualidade de vida relacionada à saúde de crianças e adolescentes Portugueses. Psicologia, Reflexão e Crítica, 25(2), 230-237. https://doi.org/10.1590/S0102-79722012000200004

Matos, M. G., Gaspar, T., Ferreira, M., Tomé, G., Camacho, I., Reis, M., ... Equipa Aventura Social. (2012). Keeping a focus on self-regulation and competence: "find your own style", A school based program targeting at risk adolescents. Journal of Cognitive and Behavioral Psychotherapies, 12(1), 39-48.

Matos, M. G., Sampaio, D., Baptista, I., \& Equipa Aventura Social. (2012). Adolescent's health education and promotion in Portugal: a case study of planning for sustainable practice. In O. Samdal \& L. Rowling (Eds.), The Implementation of health promoting schools, exploring the theories oh what, why and how (pp. 123-126). New York: Routledge Taylor \& Francis Group.

Matos, M. G., Tomé, G., Gaspar, T., Cicognani, E., \& Moreno, M. C. (2016). Youth mental health in Portugal, Italy and Spain: Key challenges for improving well-being. The European Health Psychologist, 18(3), 128-133.

Moilanen, K. L. (2007). The Adolescent Self-Regulatory Inventory: The development and validation of a questionnaire of short-term and long-term self-regulation. Journal of Youth and Adolescence, 36, 835-848. https://doi.org/10.1007/s10964-006-9107-9

Morgan, A. (2007). Frameworks for improving young people's mental well being: Assets and deficits models. WHO/HBSC Forum: Social Cohesion and Mental Health, 2007: Las Palmas, March 2007.

Pires, R., Araújo Pedrosa, A., Pereira, J., \& Canavarro, M. C. (2014). Preventing adolescent pregnancy: Biological, social, cultural, and political influences on age at first sexual intercourse. Journal of Primary Prevention, 35(4), 239-254. https://doi.org/10.1007/s10935-014-0344-5

Ravens-Sieberer, U., Gosch, A., Abel, T., Auquier, P., Bellach, B., Bruil, J., Dur, W., Power, M., Rajmil, L., \& European KIDSCREEN Group (2001). Quality of life in children and adolescents: a European public health perspective. Preventivmed, 46, 294-302. https://doi.org/10.1007/BF01321080

Ravens-Sieberer, U., Gosch, A., Rajmil, L., Erhart, M., Bruil, J., Duer, W., Auquier, P., Power, M., Abel, T., Czemy, L., Mazur, J., Czimbalmos, A., Tountas, Y., Hagquist, C., Kilroe, J. and the European KIDSCREEN Group. (2005). KIDSCREEN-52 quality-of-life measure for children and adolescents. Expert Review of Pharmacoeconomics \& Outcomes Research, 5(3), 353-364. https://doi.org/10.1586/14737167.5.3.353

Reddy, K. (2013). Evidence-Based Interventions in Low- and Middle-Income Countries: The Tigress Awakens. Journal of Adolescent Health, 52, S5-S6. https://doi.org/10.1016/j.jadohealth.2012.11.006

Roth, J., \& Brooks-Gunn, J. (2000). What do adolescents need for healthy development? Implications for youth policy. Social Policy Report, 14(1), 3-19. https://doi.org/10.1002/j.2379-3988.2000.tb00012.x 
The KIDSCREEN Group Europe. (2006). The KIDSCREEN questionnaires: quality of life questionnaires for children and adolescents. Germany, Pabst Science Publishers.

World Health Organization. (2014). Health for the world's adolescents: A second chance in the second decade. Geneva, World Health Organization.

\section{Copyrights}

Copyright for this article is retained by the author(s), with first publication rights granted to the journal.

This is an open-access article distributed under the terms and conditions of the Creative Commons Attribution license (http://creativecommons.org/licenses/by/4.0/). 